\title{
Pengembangan Potensi Desa Krembangan dari Segi Pariwisata dan Olahan Jagung
}

Christyanti Ciptaningtyas ${ }^{1}$, Dharmawan ${ }^{2}$, Anastasia Kartika ${ }^{3}$, Krisna Mega Brilian ${ }^{4}$, Reinaldi Julianto Purba $^{5}$, Sarasvati Yachamia H. ${ }^{6}$, Hee Juiling Indah B. ${ }^{7}$, Estevania Christina ${ }^{8}$, Maria Yustina Feriyani ${ }^{9}$, Juanito Putra Wibowo ${ }^{10}$, Raymundo Patria Hayu Sasmita, S.E,. M.Ak ${ }^{11}$ Universitas Atma Jaya Yogyakarta, Jl. Babarsari No.44, Janti, Caturtunggal, Kec. Depok, Kabupaten Sleman, Daerah Istimewa Yogyakarta 55281

Email: raymundo.patria@uajy.ac.id

\section{Received 12 Agustus 2021; Revised - ; Accepted for Publication 29 November 2021; Published 30 November 2021}

\begin{abstract}
Abstrak- Saat ini pembangunan tidak hanya dilakukan di perkotaan namun hingga wilayah desa. Kegiatan pengembangan dan pemberdayaan masyarakat dilakukan guna membantu menyelesaikan suatu persoalan di masyarakat. Potensi desa merupakan suatu kesanggupan, kemampuan, dan daya yang dimiliki dan mempunyai kemungkinan untuk dikembangkan guna meningkatkan kesejahteraan masyarakatnya. Desa Krembangan ialah salah satu desa yang memiliki potensinya yang dapat dikembangkan untuk kesejahteraan masyarakatnya. Potensi yang dimiliki di desa Krembangan ialah pariwisata dan pertanian yang juga menjadi salah satu dari mata pencarian utama masyarakatnya. Sektor pariwisata desa ini adalah Objek Wisata Goa Kebon dan hasil pertaniannya yaitu palawija (jagung, padi dan lainnya). Jurnal ini membahas tentang pengembangan Objek Wisata Goa Kebon dengan pembuatan Masterplan Outbond guna mendesain beberapa fasilitas outbound dan pengolahan produk pertanian berupa jagung untuk diolah menjadi beberapa olahan pangan yang memiliki nilai ekonomi. Pengolahan jagung menjadi makanan olahan seperti popcorn dan keripik jagung tortilla dengan menggunakan peralatan dapur sederhana namun dapat menghasilkan olahan yang memiliki nilai jual di pasaran dengan berbagai macam pertimbangan dari kelebihan produk tersebut.
\end{abstract}

Kata Kunci- Pengembangan, Potensi Desa, Desa Krembangan, Goa Kebon, Jagung.

Abstract - Currently, development is not only in urban but until the village .Development activities and community empowerment done to help ease a matter in the community .Potential of the village is a strength , the ability, and the owned and is likely to develop to bolster their people welfare. Krembangan village is one of the villages that can be further explored clearly hold their for their people welfare. Their potential in the village Krembangan is tourism and agriculture who also became one of primary search from the eyes of the people come from .The tourism sector the village are tourism objects Goa Kebon and yields namely secondary crops (corn , rice and other uses). This journal discuss about the development of tourism objects Goa Kebon with the master plan of several facilities outbound in order to design and manufacturing agricultural products in the form of corn to be changed into a food processed some have economic value. Processing corn to processed foods such as popcorn and chips corn tortilla with using the equipment the kitchen simple but processed can produce value in the market with different kinds of in consideration of excess of these products.

Keyword-Development, the village potential, krembangan village, Goa Kebon, corn.

\section{Pendahuluan (Heading 1)}

Desa merupakan kelompok rumah yang berbentuk kesatuan ataupun dusun yang berada diluar daerah perkotaan [1]. Desa Krembangan merupakan salah satu desa yang berada di kecamatan Panjatan, Kulon Progo, Daerah Istimewa Yogyakarta yang berjarak sekitar $30 \mathrm{~km}$ dari kota
Yogyakarta. Desa Krembangan terletak kurang lebih $2 \mathrm{~km}$ dari Ibukota Kecamatan Panjatan dengan luas 591,49 Ha. Desa Krembangan terdiri dari beberapa wilayah yang terbagi menjadi Sawah seluas 116,89 Ha, tanah kering seluas 401,31 Ha, bangunan seluas 30,22 Ha dan lain - lain seluas 43, 67 Ha. Wilayah sawah pada Desa Krembangan seluas 116, 89 Ha menggunakan beberapa sistem pengairan yaitu sistem pengairan teknis seluas $75,27 \mathrm{Ha}$, setengah semi $32,80 \mathrm{Ha}$ serta pengairan tadah hujan seluas 8,82 Ha. Ditinjau secara klimatologis desa Krembangan merupakan daerah dengan iklim tropis yang memiliki tingkat curah hujan $2000-3000$ $\mathrm{Mm} /$ tahun dan suhu udara antara $23-30^{\circ}[2]$.

Desa Krembangan memiliki beberapa potensi desa yang dapat dikembangkan untuk meningkatkan kesejahteraan masyarakat disana. Soleh (2017) mengatakan bahwa potensi desa merupakan daya atau kekuatan yang dimiliki desa untuk dikembangkan sehingga dapat memenuhi kebutuhan masyarakat dengan tujuan untuk kesejahteraan dan kemakmuran[3]. Potensi desa pada desa Krembangan seperti halnya potensi wisata alam dan beberapa potensi lainnya dari sektor pertanian. Sektor pertanian yang unggul seperti buah, sayuran dan palawija. Salah satu sektor pertanian yang unggul yaitu palawija berupa tanaman jagung. Ekowati dan Nasir (2011) mengatakan bahwa jagung menjadi salah satu bahan makanan karbohidrat yang penting di Indonesia setelah beras, namun jagung banyak juga digunakan menjadi bahan baku dalam industri dan makanan ternak[4]. Berikut merupakan klasifikasi tanaman jagung menurut ITIS (2020)[5]:

Tabel 1. Klasifikasi Tanaman Jagung

\begin{tabular}{|l|c|}
\hline Klasifikasi & Keterangan \\
\hline Kerajaan & Plantae \\
\hline Divisi & Tracheophyta \\
\hline Kelas & Magnoliopsida \\
\hline Bangsa & Poales \\
\hline Suku & Poaceae \\
\hline Marga & Zea L. \\
\hline Jenis & Zea mays L. \\
\hline
\end{tabular}

Sektor pariwisata pada Desa Krembangan yaitu Objek Wisata Goa Kebon. Soedarso dkk (2014) mengatakan bahwa pariwisata merupakan kegiatan perjalanan yang dapat dilakukan sendiri atau berkelompok dengan bepergian dari tempat tinggalnya ke tempat lain denga tujuan tidak untuk mencari penghasilan[6]. Adanya potensi desa ini dimungkinkan untuk dilakukannya pendataan potensi desa seperti pembangunan dan infrastruktur yang ada di desa yang mendukung perkembangan di desa Krembangan. Tujuan 
pengembangan pariwisata desa adalah untuk mengurangi kemiskinan, memanfaatkan sumber daya, mengembangkan budaya, melestarikan lingkungan dan alam. Meningkatkan citra suatu daerah hingga dapat mempererat hubungan dengan negara lain seperti yang diungkapkan oleh Sutawa (2012)[7].

Kegiatan kegiatan pengembangan dan pemberdayaan masyarakat merupakan salah satu bentuk pengabdian pada masyarakat yang akan membantu desa khususnya Desa Krembangan untuk mengelola potensi desa yang ada. Pengelolaan potensi desa khususnya di Desa Krembangan diharapkan dapat membantu masyarakat untuk berpikir secara inklusif dalam pengambilan keputusan, meningkatkan usaha masyarakat dalam mencapai kemakmuran dan kesejahteraan, mengoptimalkan kinerja dan fungsi para pengurus desa, membantu dan membina dalam pengembangan usaha serta menciptakan ikatan yang satu antara desa dengan lembaga pemerintahan seperti yang diungkapkan oleh Soleh (2017)[3].

\section{METODE PENGABDiAN}

Pada sub bab ini akan dijelaskan metode yang digunakan dalam pengembangan dan pemberdayaan masyarakat.

\section{A. Desain Pengabdian}

Program ini dilaksanakan dengan membuat dua buah video tentang potensi yang ada di desa tersebut dan tentang cara pengolahan jagung serta buku saku tentang potensi desa yang ada di Desa Krembangan. Video yang kami buat tentang pengolahan jagung bertujuan agar masyarakat dapat membuat produk tersebut dan dapat dijual untuk menambah penghasilan mereka. Selain itu, kami juga membuatkan desain untuk tempat outbond di wisata Goa Kebon, dimana masyarakat desa tersebut sedang berencana untuk memperbaiki fasilitas yang ada disitu, termasuk fasilitas outbond. Flowchart tahapan pengabdian dijelaskan pada gambar 1

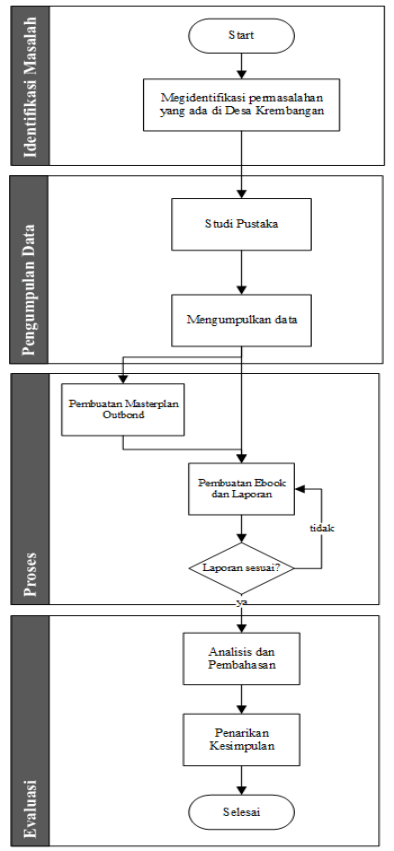

Gambar 2. Tahapan Pengabdian
Identifikasi Masalah - Proses ini dilakukan untuk mengetahui permasalahan yang sedang terjadi di masyarakat Desa Krembangan. Input dari proses identifikasi masalah ini merupakan pertanyaan yang ditujukan kepada pengurus Desa Krembangan. Output dari proses identifikasi masalah ini berupa permasalahan pada masyarakat Desa Krembangan yang kurang mendapat penyuluhan dan pelatihan bagi warga serta tidak adanya arena outbound pada tempat Wisata Goa Kebon.

Pengumpulan Data - Proses pengumpulan data dilakukan dengan cara melakukan studi pustaka melalui berbagai sumber seperti jurnal, artikel, website, buku, dan lain - lain. Data yang dicari merupakan data yang berkaitan dengan topik yang akan dibahas yaitu mengenai potensi desa serta pengolahan jagung.

Proses - Pada tahapan ini dilakukan proses pengolahan data dengan membuat masterplan outbound yang dibuat menggunakan software Sketchup dan Lumion.

Evaluasi - Pada tahapan ini dilakukan proses evaluasi untuk mengetahui besarnya efek yang ditimbulkan dari perspektif masyarakat apabila telah membaca ebook yang dibuat. Kemudian, dilakukan analisis untuk ditarik kesimpulan antara hasil dengan tujuan kegiatan pengembangan dan pemberdayaan masyarakat.

\section{B. Bahan dan Alat}

Bahan dan Alat yang digunakan yaitu Software Sketchup dan Lumion serta perangkat keras laptop untuk membuat masterplan program kerja 1 .

Sedangkan untuk program kerja 2 membutuhkan bahan dan peralatan dapur untuk memasak olahan jagung. Peralatan tersebut berupa kompor, wajan, spatula, pisau, talenan, baskom,sendok, piring, timbangan, tutup wajan. Bahan yang diperlukan untuk membuat berbagai olahan jagung yaitu jagung manis kupas, garam, gula merah, gila pasir, mentega, telur, air, baking powder, bawang putih bubuk, pewarna makanan, keju, bubuk cabai, oreo, tepung terigu, kaldu bubuk, dan coklat putih.

C. Sampel

Program ini dilaksanakan di Desa Krembangan Dukuh VII, Kecamatan Panjatan, Kulon Progo. Program dilaksanakan oleh masyarakat Desa Krembangan, Kecamatan Panjatan, Kulon Progo.

\section{Parameter}

Desa Krembangan memiliki potensi yang kaya akan sumber daya alam yang dapat dimanfaatkan untuk memberikan keuntungan bagi masyarakat desa. Dengan pelaksanaan kegiatan pengembangan dan pemberdayaan masyarakat ini, diharapkan masyarakat desa Krembangan dapat lebih produktif untuk mengolah potensi yang ada menjadi suatu produk yang nantinya dapat dijual dan dapat meningkatkan pendapatan bagi masyarakat di desa Krembangan.

Selain itu, pelaksanaan kegiatan pengembangan dan pemberdayaan masyarakat ini juga diharapkan dapat membantu masyarakat mengelola wisata Goa Kebon yaitu dengan adanya desain untuk tempat outbond di daerah wisata Goa Kebon sehingga wisata ini dapat berkembang lebih baik lagi dan dikenal oleh masyarakat luas. 
III. HASIL DAN PEMBAHASAN

A. Program Kerja 1 (Potensi Objek Wisata Goa Kebon) Hasil - Hasil dari program kerja 1 berupa ebook potensi desa Objek Wisata Goa Kebon

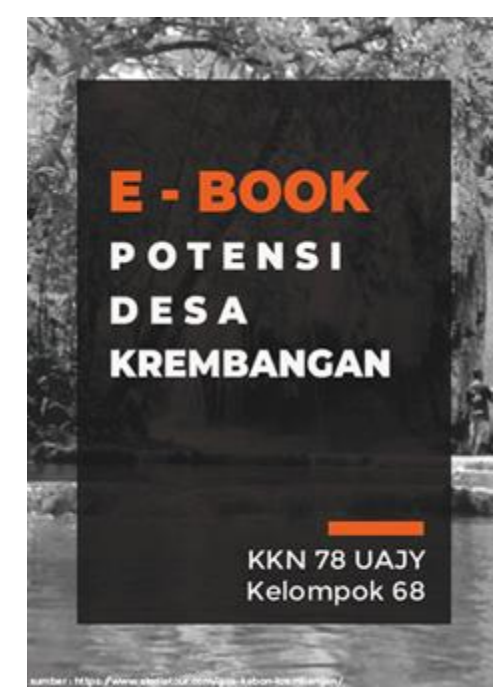

Gambar 3. Ebook potensi desa Krembangan : Cover

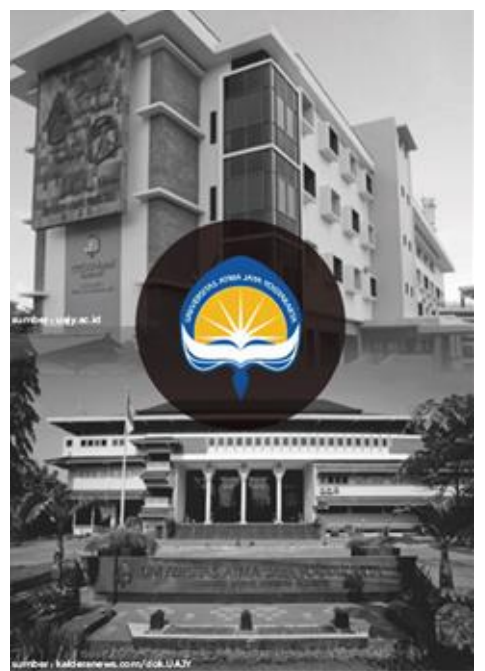

Gambar 4. Gambar dan Logo Atmajaya
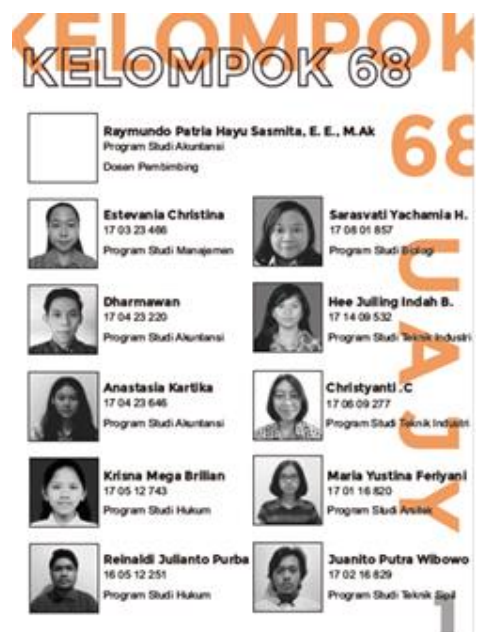

Gambar 5. Data Anggota Kelompok 68

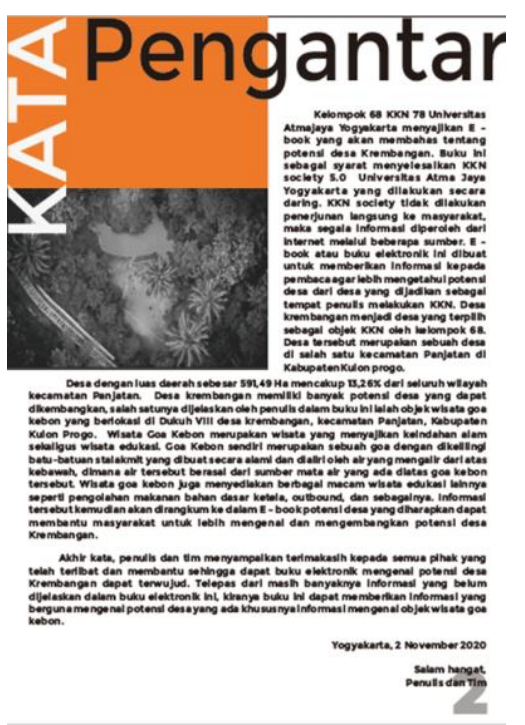

Gambar 6. Kata Pengantar

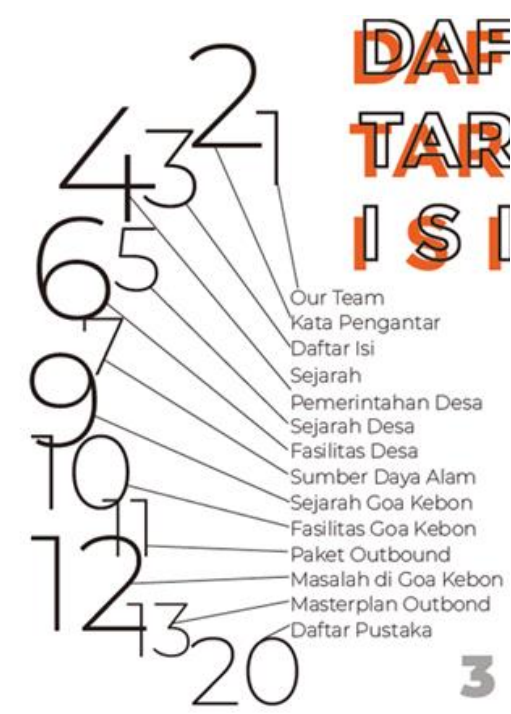

Gambar 7. Daftar Isi

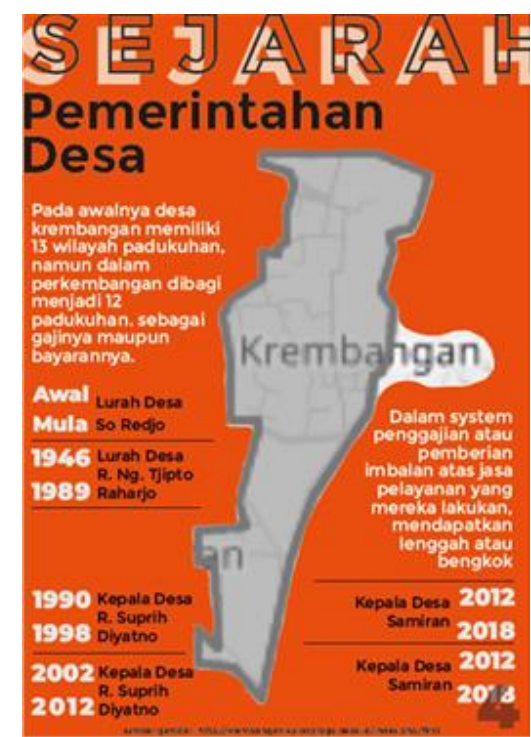

Gambar 8. Sejarah Pemerintahan Desa Krembangan 


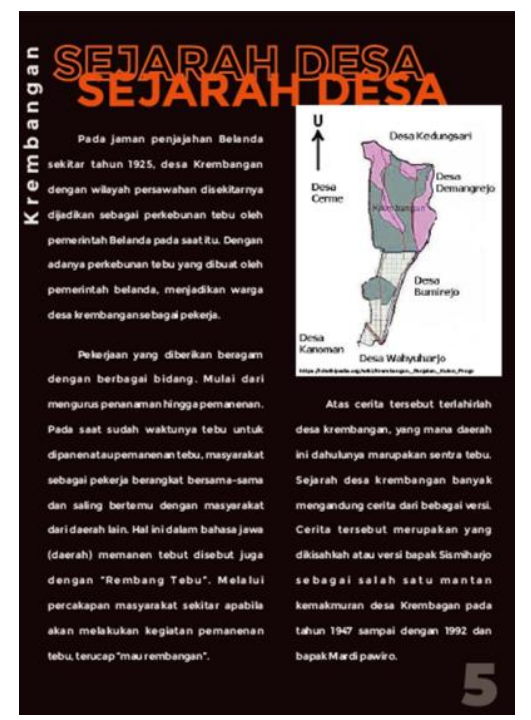

Gambar 9. Sejarah Desa Krembangan

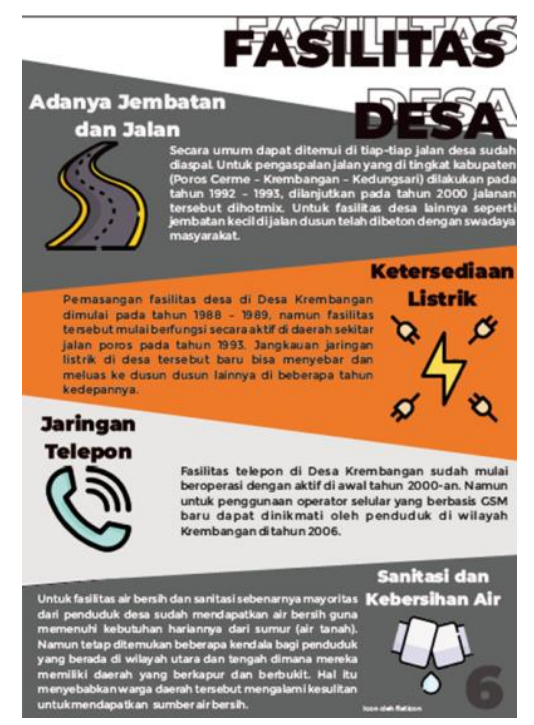

Gambar 10. Fasilitas Desa Krembangan

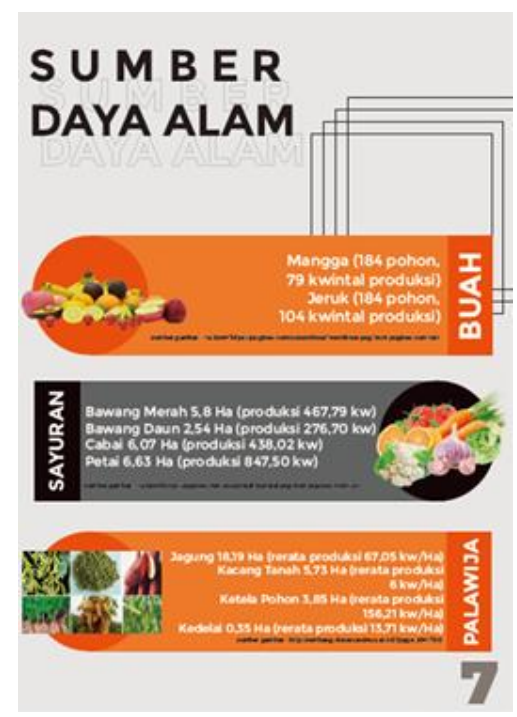

Gambar 11. Sumber Daya Alam

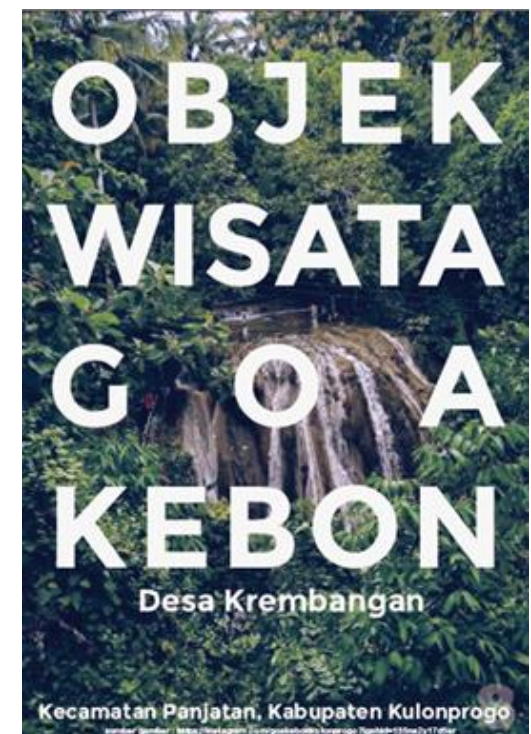

Gambar 12. Cover Potensi Desa Goa Kebon

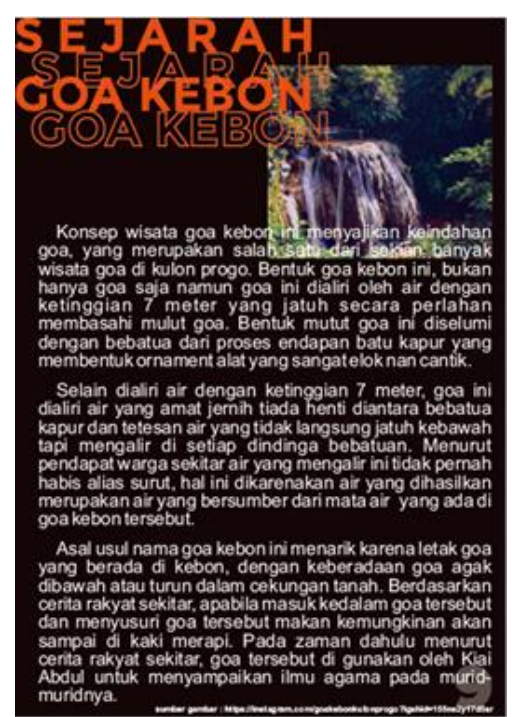

Gambar 13. Sejarah Goa Kebon

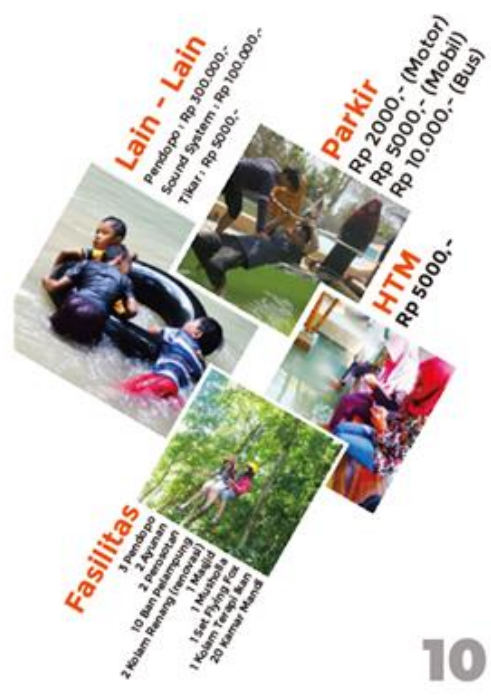

Gambar 14. Fasilitas Goa Kebon 


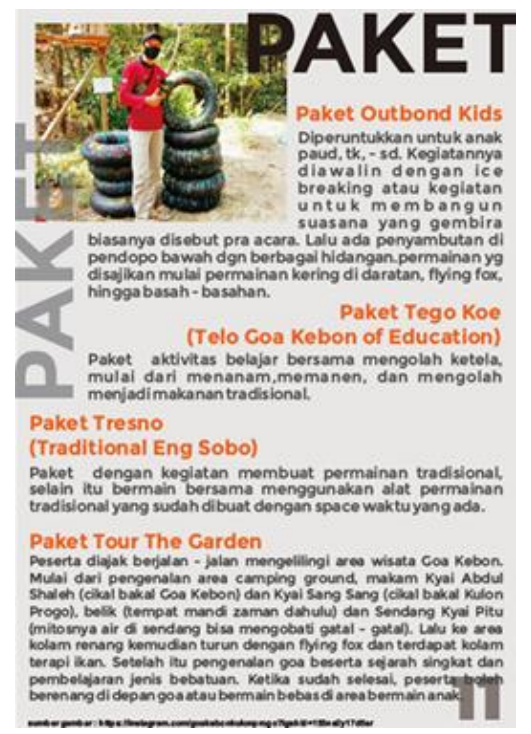

Gambar 15. Paket Wisata Goa Kebon

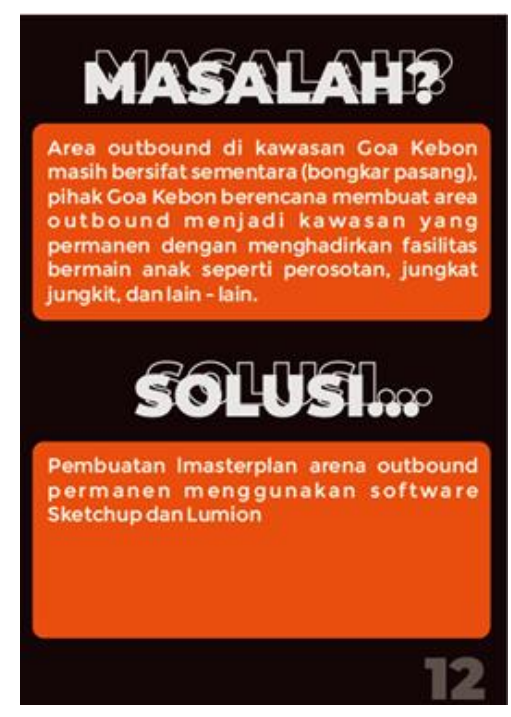

Gambar 16. Masalah dan Solusi Objek Wisata Goa Kebon

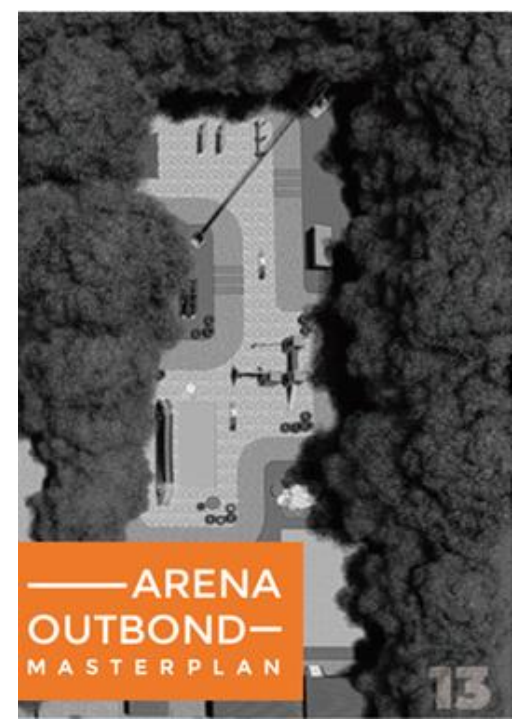

Gambar 17. Cover Masterplan Arena Outbound

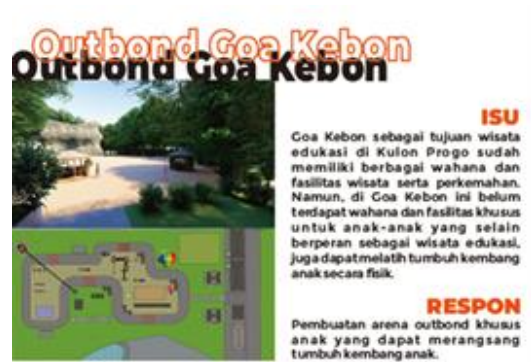

ISI DAN FASILITAS OUTBOND ANAK

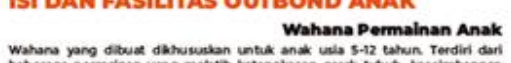

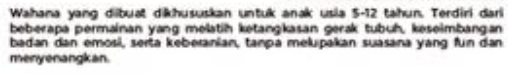
Area Penunjang
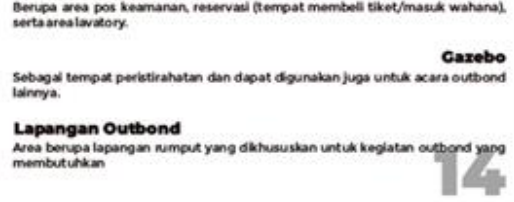

Gambar 18. Isu dan Respon Outbound Goa Kebon

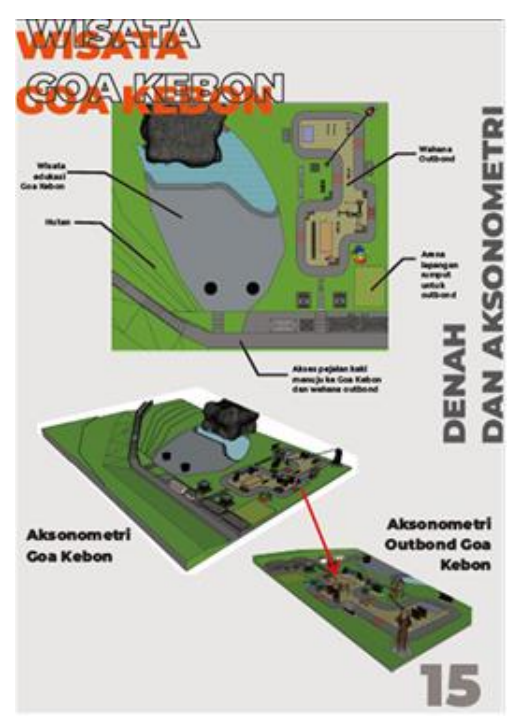

Gambar 19. Denah dan Aksonometri Goa Kebon

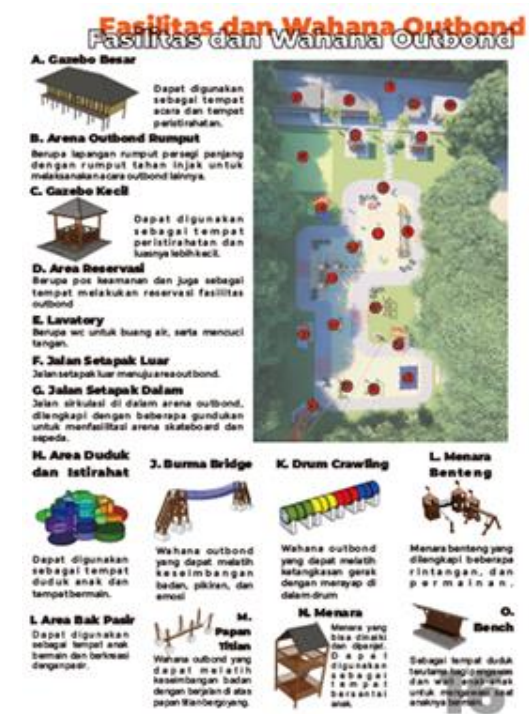

Gambar 20. Fasilitas dan Wahana Outbound Goa Kebon 


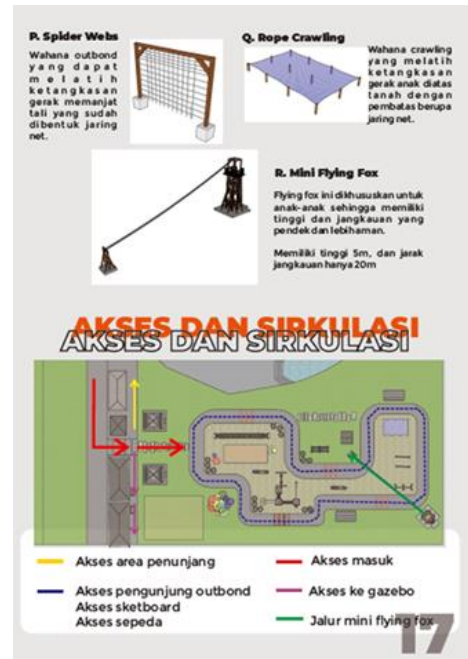

Gambar 21. Akses dan Surkulasi Arena Outbound Goa Kebon

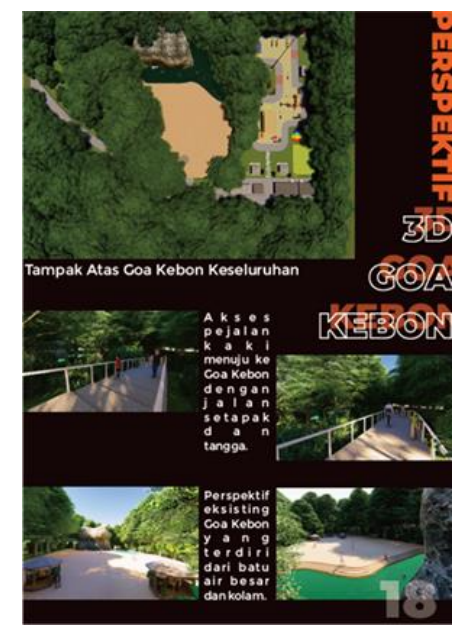

Gambar 22. Perspektif 3d Goa Kebon

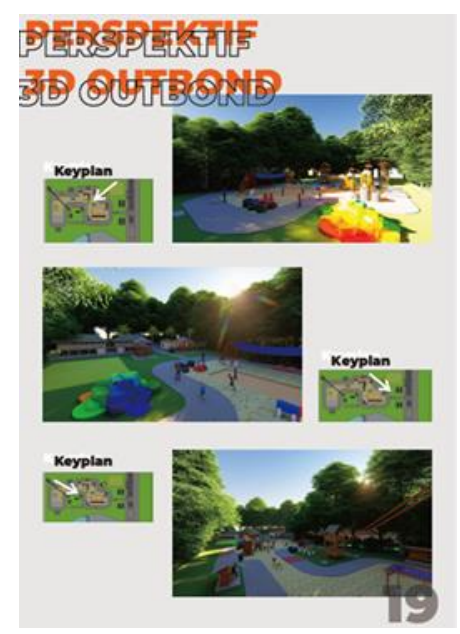

Gambar 23. Perspektif 3D Outbound

Pembahasan - Goa Kebon menjadi salah satu daya tarik wisatawan di Desa Krembangan, Kulon Progo. Hal tersebut membuat pengurus objek wisata tersebut terus melakukan inovasi dan pengembangan. Salah satu pengembangan yang dilakukan yaitu melakukan inovasi terhadap arena outbound.
Pada awalnya, arena outbound pada objek wisata tersebut hanya memiliki beberapa wahana yang terbatas dan tidak bersifat permanen. Jenis arena outbound yang telah tersedia yaitu fun outbound yang bertujuan hanya untuk menciptakan suasana yang menyenangkan serta tidak membutuhkan peralatan atau wahana yang khsusus. Oleh sebab itu penulis berupaya mengusulkan masterplan arena outbound permanen dalam rangka membantu mengembangkan objek wisata Goa Kebon. Arena outbound yang diusulkan bertujuan untuk perkembangan fisik seperti ketangkasan gerak tubuh) serta perkembangan mental anak. Pada arena outbound tersebut, anak akan dilatih mengendalikan diri secara mental, meningkatkan kerjasama, pantang menyerah, rasa gigih, serta keberanian. Nantinya arena outbound dibagi menjadi dua arena utama yaitu wahana outbound dan area penunjang. Whana outbound dibuat khsusus untuk anak berusia 5 hingga 12 tahun yang terdiri dari wahana untuk melatih gerak tubuh dan ketangkasan, keseimbangan badan dan mental tetapi dalam suasana yang menyenangkan. Sedangkan arena penunjang terdiri dari pos keamanan, gazebo, area reservasi atau tempat pembelian tiket serta alrea lavatory. Rencana masterplan arena outbound akan ditampilkan pada gambar 4.

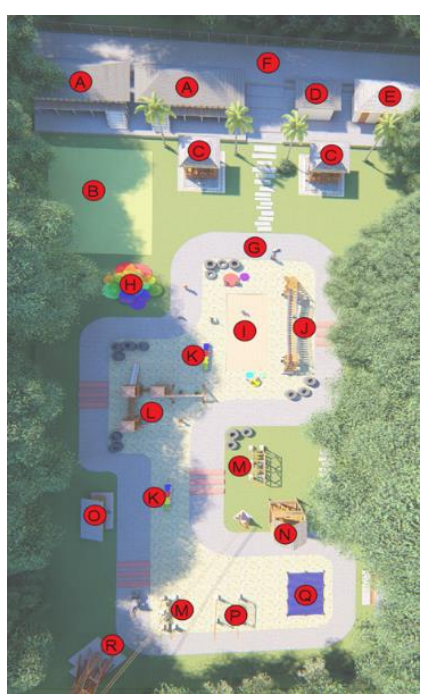

Gambar 24. Rencana Masterplan Arena Outbound Anak

Fasilitas yang terdapat pada rencana masterplan arena outbound anak serta fungsinya akan dijelaskan pada tabel 2.

Tabel 2. Fasilitas dan Fungsi pada Masterplan arena Outbound Anak

\begin{tabular}{|c|c|c|c|}
\hline Area & Ilustrasi & Nama & Fungsi \\
\hline \multirow[t]{2}{*}{$\begin{array}{l}\text { Wahana } \\
\text { Outbound }\end{array}$} & - & $\begin{array}{c}\text { B. } \\
\text { Lapangan } \\
\text { Outbound }\end{array}$ & $\begin{array}{l}\text { Area berupa } \\
\text { lapangan rumput } \\
\text { (dapat diinjak) yang } \\
\text { dikhususkan untuk } \\
\text { kegiatan outbound } \\
\text { yang membutuhkan } \\
\text { lapangan kosong }\end{array}$ \\
\hline & - & $\begin{array}{l}\text { I. Bak } \\
\text { Pasir }\end{array}$ & $\begin{array}{lr}\text { Dapat digunakan } \\
\text { sebagai tempat anak } \\
\text { bermain } \\
\text { berkreasi } \\
\text { pasir. }\end{array}$ \\
\hline
\end{tabular}


Tabel 2. Lanjutan Fasilitas dan Fungsi pada Masterplan arena Outbound Anak

\begin{tabular}{|c|c|c|c|}
\hline Area & Ilustrasi & Nama & Fungsi \\
\hline \multirow{6}{*}{$\begin{array}{l}\text { Wahana } \\
\text { Outbound }\end{array}$} & & $\begin{array}{c}J . \\
\text { Burma } \\
\text { Bridge }\end{array}$ & $\begin{array}{l}\text { Wahana outbound } \\
\text { yang memberikan } \\
\text { manfaat bagi } \\
\text { perkembangan fisik } \\
\text { anak dengan berlatih } \\
\text { menyeimbangkan } \\
\text { dan menyelaraskan } \\
\text { gerakan tubuh. } \\
\text { Secara mental, dapat } \\
\text { melatih } \\
\text { keseimbangan } \\
\text { emosi, keberanian, } \\
\text { serta pantang } \\
\text { menyerah untuk } \\
\text { mencapai tujuan. }\end{array}$ \\
\hline & & $\begin{array}{c}\text { K.Drum } \\
\text { Crawlin } \\
g\end{array}$ & $\begin{array}{l}\text { Wahana outbound } \\
\text { yang dapat melatih } \\
\text { ketangkasan gerak } \\
\text { dengan merayap di } \\
\text { dalam drum }\end{array}$ \\
\hline & & $\begin{array}{c}\text { L. } \\
\text { Menara } \\
\text { Benteng }\end{array}$ & $\begin{array}{l}\text { Berupa menara kecil } \\
\text { menyerupai benteng } \\
\text { yang dilengkapi } \\
\text { dengan beberapa } \\
\text { rintangan. } \\
\text { Merupakan } \\
\text { gabungan wahana } \\
\text { mini flying fox, } \\
\text { ayunan, serta burma } \\
\text { bridge yang } \\
\text { dirangkai menjadi } \\
\text { suatu instalasi } \\
\text { menyerupai benteng } \\
\text { sehingga dapat } \\
\text { menciptakan } \\
\text { suasana yang } \\
\text { menyenangkan. }\end{array}$ \\
\hline & & $\begin{array}{c}\text { M. } \\
\text { Papan } \\
\text { Titian }\end{array}$ & $\begin{array}{l}\text { Wahana outbound } \\
\text { yang dapat melatih } \\
\text { keseimbangan badan } \\
\text { dengan berjalan di } \\
\text { atas papan titian } \\
\text { bergoyang }\end{array}$ \\
\hline & & $\begin{array}{c}\text { N. } \\
\text { Menara }\end{array}$ & $\begin{array}{l}\text { Menara yang bisa } \\
\text { dinaiki dan dipanjat. } \\
\text { Dapat digunakan } \\
\text { sebagai tempat } \\
\text { bersantai anak }\end{array}$ \\
\hline & & $\begin{array}{c}\text { P.Spider } \\
\text { Webs }\end{array}$ & $\begin{array}{l}\text { Wahana memanjat } \\
\text { dengan simpul- } \\
\text { simpul tali yang } \\
\text { dibuat sedemikian } \\
\text { rupa sehingga } \\
\text { menjadi pijakan dan } \\
\text { dapat dipanjat. } \\
\text { Wahan ini yang } \\
\text { dapat melatih } \\
\text { ketangkasan gerak } \\
\text { tubuh. }\end{array}$ \\
\hline
\end{tabular}

Tabel 2. Lanjutan Fasilitas dan Fungsi pada Masterplan arena Outbound Anak

\begin{tabular}{|c|c|c|c|}
\hline Area & Ilustrasi & Nama & Fungsi \\
\hline \multirow[b]{2}{*}{$\begin{array}{l}\text { Wahana } \\
\text { Outbound }\end{array}$} & & $\begin{array}{l}\text { Q. Rope } \\
\text { Crawling }\end{array}$ & $\begin{array}{l}\text { Wahana } \\
\text { crawling } \\
\text { yang melatih } \\
\text { ketangkasan } \\
\text { gerak anak } \\
\text { diatas tanah } \\
\text { dengan } \\
\text { pembatas } \\
\text { berupa jaring } \\
\text { net. }\end{array}$ \\
\hline & & $\begin{array}{c}\text { R.Mini } \\
\text { Flying fox }\end{array}$ & $\begin{array}{l}\text { Flying fox ini } \\
\text { dikhususkan } \\
\text { untuk anak- } \\
\text { anak } \\
\text { sehingga } \\
\text { memiliki } \\
\text { tinggi dan } \\
\text { jangkauan } \\
\text { yang pendek } \\
\text { dan lebih } \\
\text { aman. } \\
\text { Memiliki } \\
\text { tinggi } 5 \mathrm{~m} \text {, } \\
\text { dan jarak } \\
\text { jangkauan } \\
\text { hanya } 20 \mathrm{~m} \text {. }\end{array}$ \\
\hline \multirow{5}{*}{$\begin{array}{c}\text { Area } \\
\text { Penunjang }\end{array}$} & & $\begin{array}{c}\text { A. Gazebo } \\
\text { Besar }\end{array}$ & $\begin{array}{l}\text { Dapat } \\
\text { digunakan } \\
\text { sebagai } \\
\text { tempat acara } \\
\text { dan tempat } \\
\text { peristirahatan }\end{array}$ \\
\hline & & $\begin{array}{l}\text { C. Gazebo } \\
\text { Kecil }\end{array}$ & $\begin{array}{l}\text { Dapat } \\
\text { digunakan } \\
\text { sebagai } \\
\text { tempat } \\
\text { peristirahatan } \\
\text { dan luasnya } \\
\text { lebih kecil }\end{array}$ \\
\hline & - & $\begin{array}{c}\text { D. Area } \\
\text { Reservasi }\end{array}$ & $\begin{array}{l}\text { Berupa pos } \\
\text { keamanan } \\
\text { dan juga } \\
\text { sebagai } \\
\text { tempat } \\
\text { melakukan } \\
\text { reservasi } \\
\text { fasilitas } \\
\text { outbound }\end{array}$ \\
\hline & - & E.Lavatory & $\begin{array}{l}\text { Berupa wc } \\
\text { untuk buang } \\
\text { air, serta } \\
\text { mencuci } \\
\text { tangan }\end{array}$ \\
\hline & - & $\begin{array}{l}\text { H. Area } \\
\text { Duduk }\end{array}$ & $\begin{array}{l}\text { Dapat } \\
\text { digunakan } \\
\text { sebagai } \\
\text { tempat } \\
\text { duduk anak } \\
\text { dan tempat } \\
\text { bermain }\end{array}$ \\
\hline
\end{tabular}


Tabel 2. Lanjutan Fasilitas dan Fungsi pada Masterplan arena Outbound Anak

\begin{tabular}{|c|c|c|c|}
\hline Area & Ilustrasi & Nama & Fungsi \\
\hline $\begin{array}{c}\text { Area } \\
\text { Penunjang }\end{array}$ & & O. Bench & $\begin{array}{l}\text { Sebagai tempat duduk } \\
\text { terutama bagi pengawas } \\
\text { dan wali anak-anak untuk } \\
\text { mengawasi saat anaknya } \\
\text { bermain. Ditempatkan di } \\
\text { beberapa titik pada area } \\
\text { outbound. }\end{array}$ \\
\hline
\end{tabular}

B. Program Kerja 2 (Penyuluhan Pengolahan Jagung) Berikut merupakan hasil dari program kerja 2 yaitu penyuluhan pengolahan jagung berupa ebook buku saku yang ditampilkan pada gambar 5 .

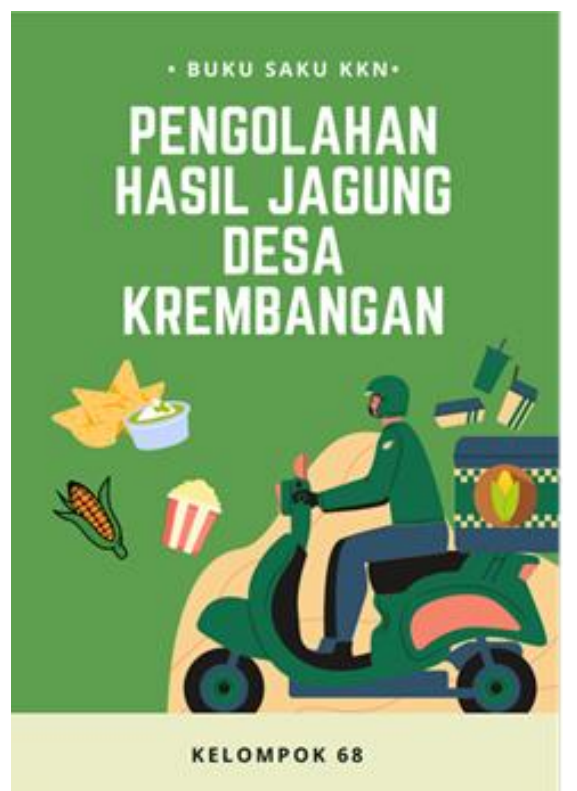

Gambar 25. Cover Buku Saku

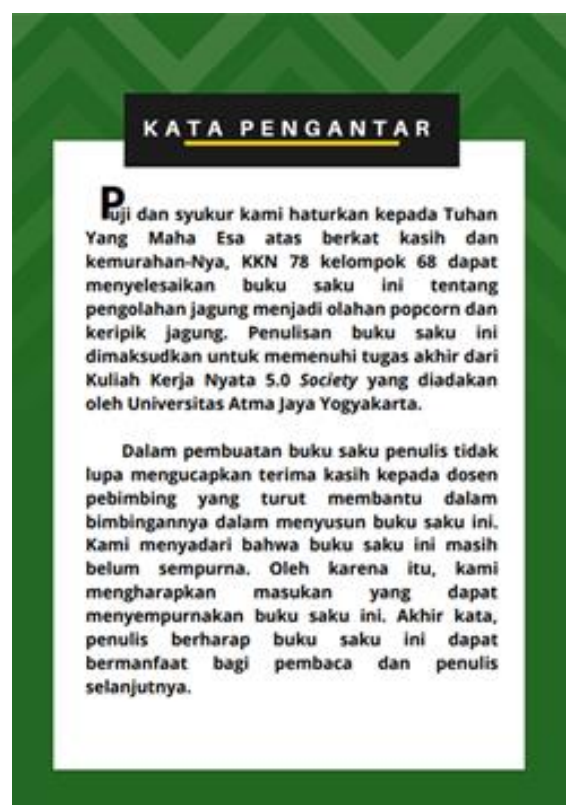

Gambar 26. Kata Pengantar Buku Saku
LATAR BELAKANG

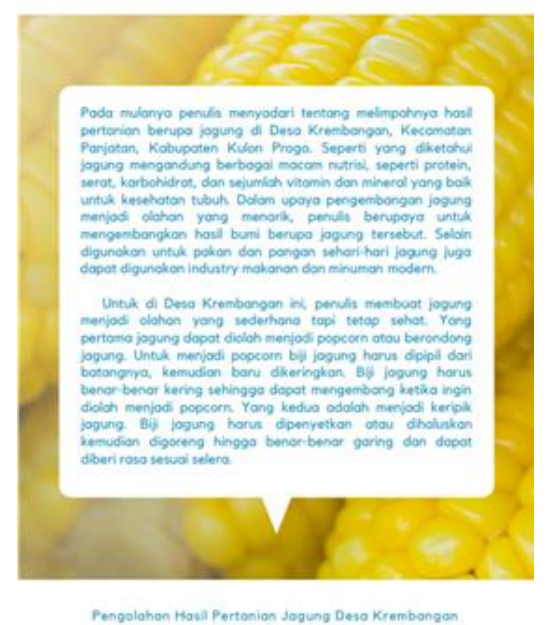

Gambar 27. Latar Belakang Buku Saku

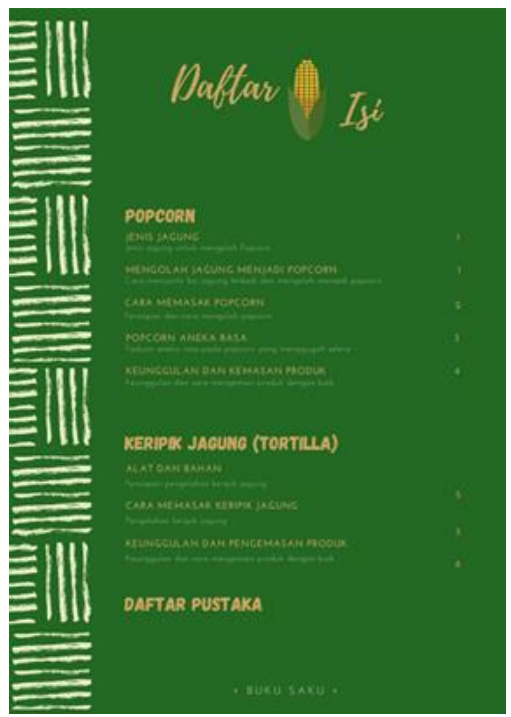

Gambar 28. Daftar Isi Buku Saku

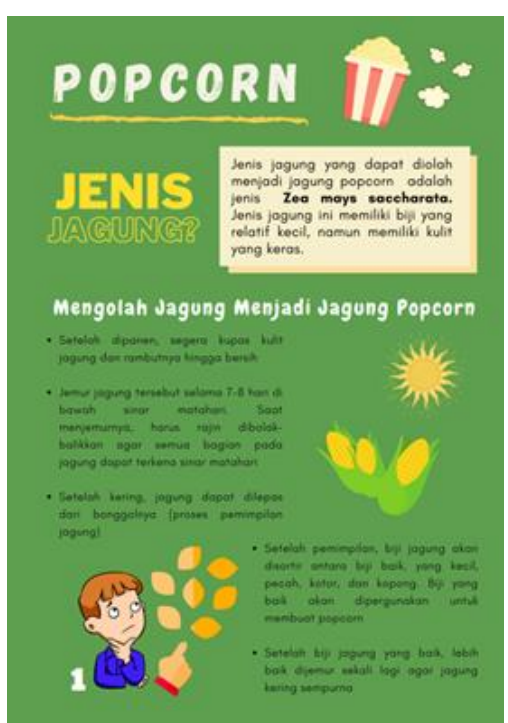

Gambar 29. Produk Olahan berupa Popcorn 


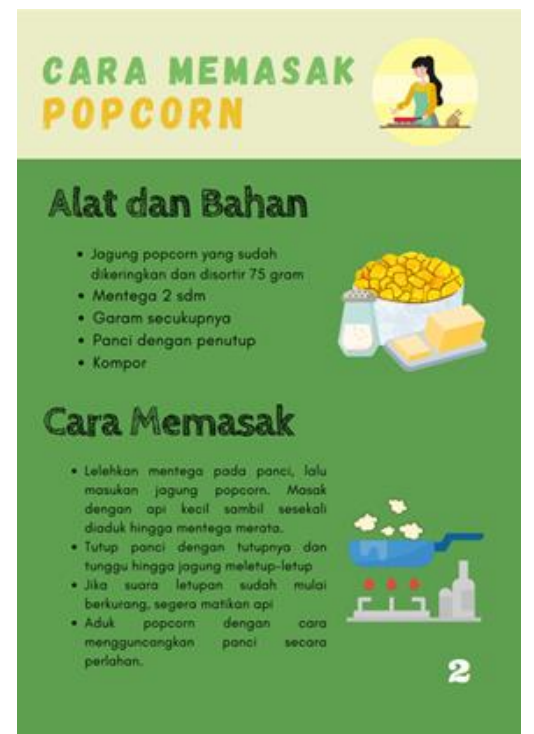

Gambar 30. Cara Mengelola Popcorn

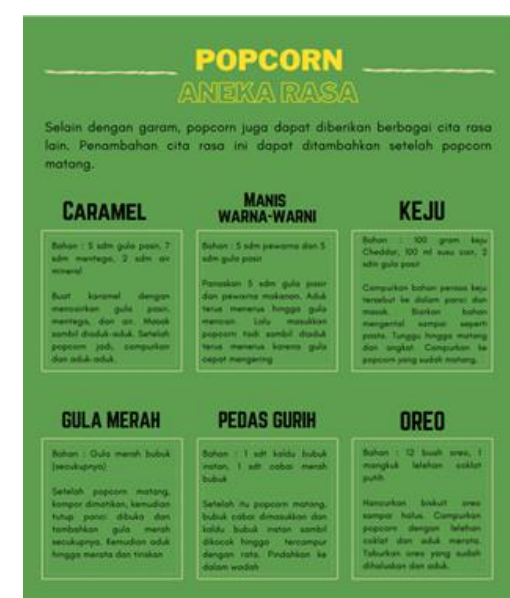

$\mathbf{3}$

Gambar 31. Pengolahan Popcorn Aneka Rasa

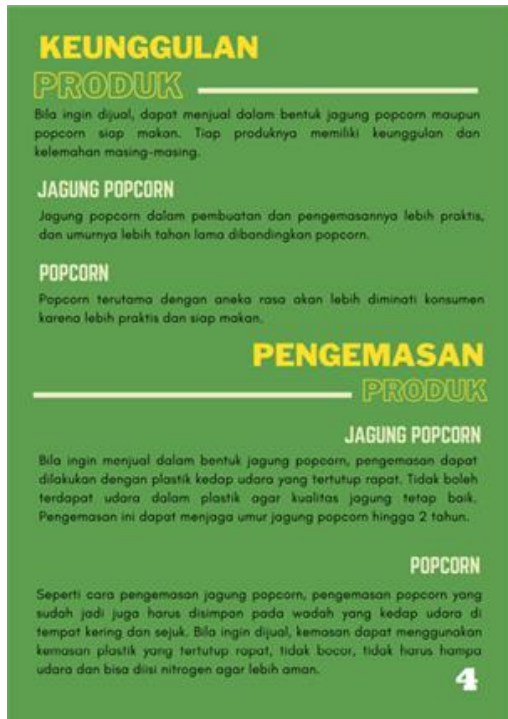

Gambar 32. Keunggulan dan Pengemasan Produk Popcorn

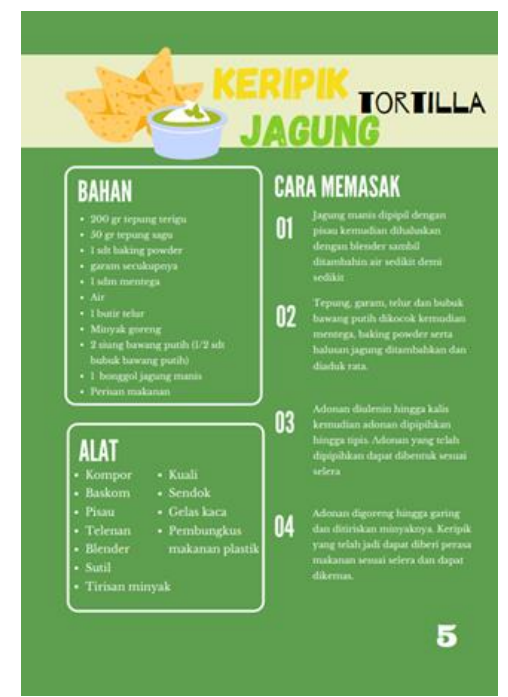

Gambar 33. Proses Pengolahan Keripik Jagung Tortilla

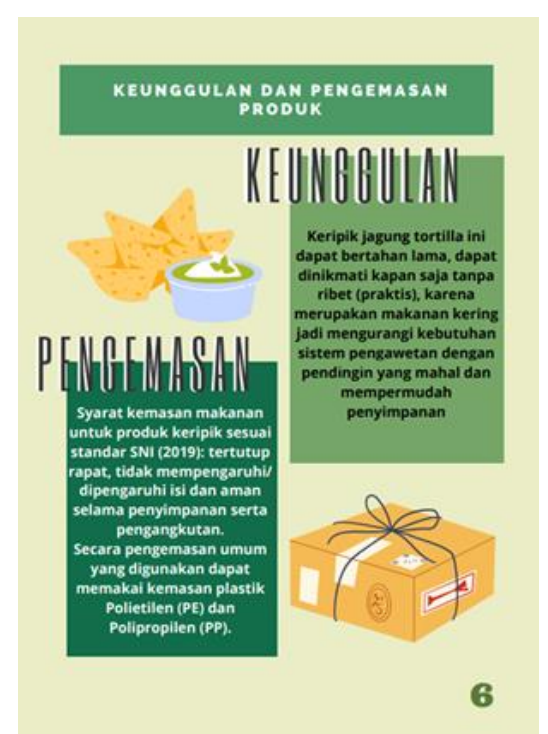

Gambar 34. Keunggulan dan Pengemasan Produk Keripik Jagung Tortilla

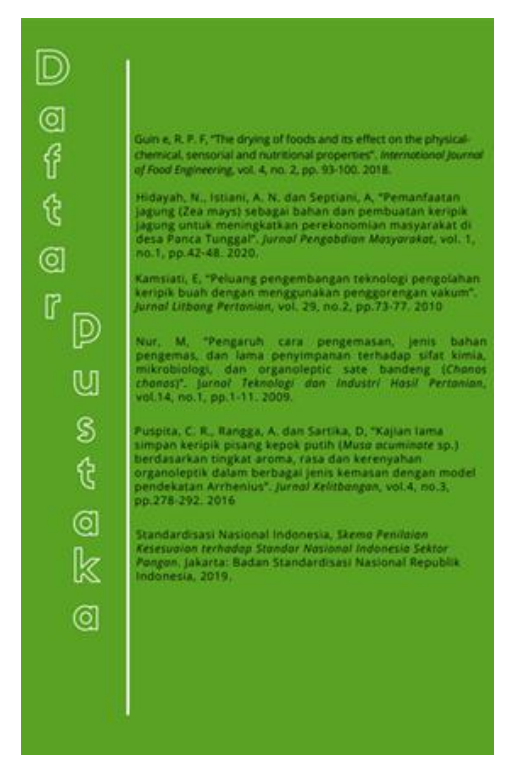

Gambar 35. Daftar Pustaka Buku Saku 
Pembahasan - Produk olahan jagung dipilih karena banyak dipakai sebagai salah satu bahan pangan dan ketahanan pangan untuk memenuhi kebutuhan rumah tangga karena aman, bermutu baik, memiliki jumlah yang cukup serta harga yang terjangkau. Kandungan mineral dan antioksidan pada tubuh dapat ditemukan pada jagung seperti fosfor, magnesium, sengm besi dan tembaga. Fungsi fosfor ialah untuk memelihara pertumbuhan dan kesehatan tulang, serta fungsi ginjal. Sedangkan magnesium dapat mempertahankan denyut jantung serta menjaga kekuatan tulang[8]. Jagung juga memiliki kekayaan komponen pangan fungsional seperti dietary fiber yaitu serat pangan yang dibutuhkan tubuh, asam lemak esensial, pro - vitamin A atau $\beta$-karoten, dan lain - lain. Berikut merupakan kandungan gizi pada jagung yang ditampilkan dalam tabel 3 seperti yang diungkapkan Suarni dan Yasin (2011)[9].

Tabel 3. Kandungan Gizi

\begin{tabular}{|c|c|c|c|c|}
\hline \multirow[t]{2}{*}{ Kandungan } & \multicolumn{2}{|c|}{$\begin{array}{c}\text { Satuan/ } 100 \mathrm{~g} \\
\text { bahan }\end{array}$} & \multicolumn{2}{|c|}{$\begin{array}{l}\text { Komposisi kimia dan } \\
\text { zat gizi jagung kuning } \\
\text { pipilan per } 100 \mathrm{~g}\end{array}$} \\
\hline & $\begin{array}{l}\text { Jagung } \\
\text { Manis }\end{array}$ & $\begin{array}{l}\text { Jagung } \\
\text { Biasa }\end{array}$ & Komponen & Jumlah \\
\hline Energi & $\begin{array}{c}96,0 \\
\mathrm{cal}\end{array}$ & $129 \mathrm{cal}$ & Energi & $\begin{array}{c}307,00 \\
\mathrm{cal}\end{array}$ \\
\hline Protein & $3,5 \mathrm{~g}$ & $4,1 \mathrm{~g}$ & Protein & $7,90 \mathrm{~g}$ \\
\hline Lemak & $1,0 \mathrm{~g}$ & $1,3 \mathrm{~g}$ & Lemak & $3,40 \mathrm{~g}$ \\
\hline Karbohidrat & $22,8 \mathrm{~g}$ & $30,3 \mathrm{~g}$ & Karbohidrat & $63,60 \mathrm{~g}$ \\
\hline Kalsium & $3,0 \mathrm{mg}$ & $5,0 \mathrm{mg}$ & $\mathrm{Ca}$ & $\begin{array}{c}148,00 \\
\mathrm{mg}\end{array}$ \\
\hline Fosfor & $111 \mathrm{mg}$ & $\begin{array}{c}108,0 \\
\mathrm{mg}\end{array}$ & $\mathrm{Fe}$ & $2,10 \mathrm{mg}$ \\
\hline Besi & $0,7 \mathrm{mg}$ & $1,1 \mathrm{mg}$ & Vitamin A & $\begin{array}{c}440,00 \\
\text { SI } \\
\end{array}$ \\
\hline Vitamin A & $400 \mathrm{SI}$ & $117,0 \mathrm{SI}$ & Vitamin B1 & $0,33 \mathrm{mg}$ \\
\hline Vitamin B & $\begin{array}{c}0,15 \\
\mathrm{mg}\end{array}$ & $\begin{array}{c}0,18 \\
\mathrm{mg}\end{array}$ & Air & $24,00 \%$ \\
\hline Vitamin C & 12,0 & $9,0 \mathrm{mg}$ & \multirow{2}{*}{$\begin{array}{l}\text { Bagian yang } \\
\text { dapat } \\
\text { dimakan }\end{array}$} & \multirow[t]{2}{*}{$90,00 \%$} \\
\hline Air & $72,7 \mathrm{~g}$ & $63,5 \mathrm{~g}$ & & \\
\hline
\end{tabular}

BPOM (2016) menyatakan bahwa jagung merupakan bahan pangan yang dapat diolah menjadi suatu produk tanpa perlu menggunakan bahan tambahan[10]. Produk olahan jagung yang dipilih yaitu popcorn dan tortilla atau keripik jagung. Proses pembuatan popcorn dengan cara memanaskan 2 sdm mentega ke dalam panci, kemudian memasukkan jagung popcorn dan dimasak menggunakan api kecil sambil sesekali diaduk merata. Setelah itu panci ditutup dan tunggu hingga timbul letupan pada jagung. Apabila suara letupan sudah mulai berkurang, maka api pada kompor dapat dimatikan lalu aduk perlahan untuk memastikan popcorn matang secara merata seperti yang telah dibuktikan oleh Khan dan Ahmed (2014)[11]. Proses tersebut juga berlaku untuk pembuatan popcorn dengan caramel ataupun gula merah.
Proses pembuatan keripik jagung pertama - tama memipil jagung menggunakan pisau lalu jagung tersebut ditambahakan sedikit air lali dihaluskan dengan blender. Kemudian mengocok lepas tepung terigu 200g, tepung sagu $50 \mathrm{~g}, 1 / 2$ sdt bubuk bawang putih dan 1 butir putih telur lalu ditambahkan mentega $1 \mathrm{sdm}$, baking powder 1sdt dan jagung yang telah dihaluskan. Bahan yang sudah tercmpur kemudian diuleni hingga kalis lalu dipipihkan sampai tipis menggunakan gelas kaca. Adonan yang telah pipih lalu dipotong dan digoreng hingga garing seperti yang telah dibuktikan oleh Hidayah dkk (2020)[12].

\section{KESIMPULAN}

Potensi daerah dapat mempengaruhi kodisi perekonomian suatu daerah. Salah satunya adalah di Desa Krembangan yang terletak di Kabupaten Kulon Progo, Daerah Istimewa Yogyakarta. Potensi alam dan hasil bumi yang telah tersedia seharusnya dapat lebih diberdayakan dengan baik. Sehingga pada akhirnya semua sumber daya dapat digunakan dan dapat meningkatkan taraf ekonomi. Pembuatan masterplan outbound dan penyuluhan atau sosialisasi tentang pengolahan jagung dapat menjadi salah satu cara untuk membuat Desa Krembangan menjadi lebih inovatif dan terus berkembang. Pada akhirnya masyarakat Desa Krembangan dapat lebih produktif dan tercipta kehidupan yang makmur dan sejahtera.

\section{UCAPAN TERIMAKASIH}

Terimakasih kepada LPPM dan Universitas Atma Jaya Yogyakarta yang telah menyelenggarakan kegiatan pengembangan dan pemberdayaan masyarakat.

\section{DAFTAR PUSTAKA}

[1] Kementerian Pendidikan dan Kebudayaan Republik Ind; Badan Pengembangan dan Pembinaan Bahasa, "Desa," 2016. [Online]. Available: https://kbbi.kemdikbud.go.id/entri/desa. [Accessed: 17Nov-2020].

[2] Udaningsih, Kapanewon Panjatan Dalam Angka 2020 |. Kulon Progo: (c) BPS Kabupaten Kulon Progo/BPSStatistics ofKulon Progo Regency, 2020.

[3] Ahmad Soleh, "STRATEGI PENGEMBANGAN POTENSI DESA," Sungkai, vol. 5, no. No.1, pp. 3252, 2017.

[4] D. E. and M. Nasir, "PERTUMBUHAN TANAMAN JAGUNG (ZEA MAYS L.) VARIETAS BISI-2 PADA PASIR REJECT DAN PASIR ASLI DI PANTAI TRISIK KULONPROGO," Mns. dan Lingkung., vol. 18, no. 3, pp. 220-230, 2011, doi: https://doi.org/10.22146/jml.18445.

[5] ITIS, "Zea mays L.," 2020. [Online]. Available: https://www.itis.gov/servlet/SingleRpt/SingleRpt?searc h_topic=TSN\&search_value $=42269 \#$ \#ull. [Accessed: 16-Nov-2020].

[6] W. Soedarso, Muchammad Nurif, "POTENSI DAN KENDALA PENGEMBANGAN PARIWISATA BERBASIS KEKAYAAN ALAM DENGAN PENDEKATAN MARKETING PLACES (STUDI KASUS PENGEMBANGAN PARIWISATA DI 
KABUPATEN BOJONEGORO)," Soc. Hum., vol. 7, no. 2, pp. 155-162, 2014.

[7] Gusti Kade Sutawa, "Issues on Bali Tourism Development and Community Empowerment to Support Sustainable Tourism Development," Procedia Econ. Financ., vol. 4, pp. 413-422, 2012, doi: https://doi.org/10.1016/S2212-5671(12)00356-5.

[8] B. Krisnamurthi, "Manfaat Jagung dan Peran Produk Bioteknologi Serealia dalam Menghadapi Krisis Pangan, Pakan dan Energi di Indonesia," Pros. Pekan Serealia Nas., pp. 978-979, 2010.

[9] Suarni and M. Yasin, "Jagung sebagai Sumber Pangan Fungsional," Iptek Tanam. Pangan, vol. 6, no. 1, pp. 41-56, 2011.

[10] BPOM RI, "Pedoman Teknis Pengawasan Periklanan Pangan Olahan," 2016.

[11] L. Khan and E. Ahmed, "FACTORS AFFECTING YIELD AND TASTE OF POPCORN: A PLANNED APPROACH," Proc. 12th Int. Conf. Stat. Sci., vol. 26, pp. 403-420, 2014.

[12] N. Hidayah, A. N. Istiani, and A. Septiani, "PEMANFAATAN JAGUNG (Zea Mays) SEBAGAI BAHAN DASAR PEMBUATAN KERIPIK JAGUNG UNTUK MENINGKATKAN PEREKONOMIAN MASYARAKAT DI ...," Al-Mu'awanah $J$. ..., vol. 1, no. 1, pp. 42-48, 2020.

\section{PENULIS}

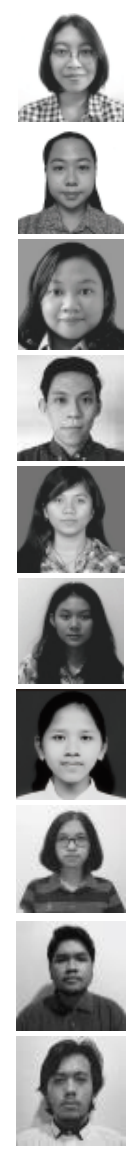

Christyanti Ciptaningtyas, prodi Teknik Industri, Fakultas Teknologi Industri, Universitas Atma Jaya Yogyakarta.

Estevania Christina, prodi Manajemen, Fakultas Bisnis dan Ekonomika, Universitas Atma Jaya Yogyakarta.

Sarasvati Yachamia H., prodi Biologi, Fakultas Tekno Biologi, Universitas Atma Jaya Yogyakarta.

Dharmawan, prodi Akuntansi, Fakultas Bisnis dan Ekonomika, Universitas Atma Jaya Yogyakarta.

Hee Juiling Indah B., prodi prodi Teknik Industri, Fakultas Teknologi Industri, Universitas Atma Jaya Yogyakarta.

Anastasia Kartika, prodi Akuntansi, Fakultas Bisnis dan Ekonomika, Universitas Atma Jaya Yogyakarta.

Krisna Mega Brilian, prodi Hukum, Fakultas Hukum, Universitas Atma Jaya Yogyakarta.

Maria Yustina Feriyani, prodi Arsitektur, Fakultas Teknik, Universitas Atma Jaya Yogyakarta.

Reinaldi Julianto Purba, prodi Hukum, Fakultas Hukum, Universitas Atma Jaya Yogyakarta.

Juanito Purba Wibowo, prodi Teknik Sipil, Fakultas Teknik, Universitas Atma Jaya Yogyakarta.
Raymundo Patria Hayu Sasmita, S.E,. M.Ak, Dosen prodi Akuntansi, Fakultas Bisnis dan Ekonomika, Universitas Atma Jaya Yogyakarta. 